Gut, 1984, 25, 79-84

\title{
Defects in serum attractant activity in different types of chronic liver disease
}

\author{
A G M YOUSIF-KADARU, I A RAJKOVIC, R J WYKE, AND ROGER WILLIAMS \\ From the Liver Unit, King's College Hospital and Medical School, London
}

SUMMARY Serum attractant activity, measured in 57 patients with chronic liver disease, was significantly reduced in $66 \%$ of the 27 patients with alcoholic liver disease and in $29 \%$ of the 17 patients with chronic active hepatitis, but was normal in 13 patients with primary biliary cirrhosis despite the presence of established cirrhosis in nearly half of them. In patients with alcoholic liver disease, but not in those with chronic active hepatitis, there was a correlation between the serum defect and severity of liver disease. The defect could not be related to the deficiency of key complement components, raised concentrations of $\mathrm{IgA}$ or $\mathrm{G}$ or the concurrent presence of bacterial infection. These findings suggest that the aetiology of liver disease may be an important factor in the development of serum attractant abnormalities.

Alcoholism and cirrhosis are associated with an increased susceptibility to a wide variety of serious, and often lethal, bacterial infections. ${ }^{1-4}$ Both Gram negative and Gram positive bacteria are involved and conditions such as septicaemia, ${ }^{3}$ spontaneous bacterial peritonitis, ${ }^{5}$ and bacterial endocarditis ${ }^{6}$ occur with unusually high frequency. The defence against pyogenic infections is dependent upon the combined actions of the humoral and cellular components of the immune systems. Activation of the complement system is an important initial step in host defence to bacterial infection, and is also responsible for directing the movement of polymorphonuclear leucocytes to the site of infection. The increased susceptibility of patients with cirrhosis to infection has been attributed to reduced levels of complement, as well as a defect in chemo-attractant activity of serum. ${ }^{7}$ Such studies as have been reported have been largely confined to patients with alcoholic cirrhosis. ${ }^{7-11}$ In the present report we describe measurements of serum attractant activity in patients with other types of chronic liver disease, including primary biliary cirrhosis and chronic active hepatitis, comparing the results. with those of patients with alcoholic liver disease.

Address for correspondence: Dr R Williams, Liver Unit, King's College Hospital Medical School. Denmark Hill, London SE5 8RX.

Received for publication 11 March 1983

\section{Methods}

PATIENTS

The 57 patients investigated had been admitted for treatment of chronic liver disease and comprised 27 with alcoholic liver disease, 13 with primary biliary cirrhosis, and 17 with surface antigen negative chronic active hepatitis. An established cirrhosis, confirmed histologically, was present in 25 of the patients with alcoholic liver disease, six with primary biliary cirrhosis, and nine with chronic active hepatitis. Seven of the cirrhotic patients in the alcoholic group had evidence of superimposed acute alcoholic hepatitis and two had fatty change only. At the time of the study seven of the patients with alcoholic cirrhosis were receiving antibiotics for culture proven bacterial infections. There was no evidence of recent infection in either the patients with chronic active hepatitis or primary biliary cirrhosis. Fifteen patients with alcoholic liver disease were receiving diuretic therapy (spironolactone $100-200 \mathrm{mg} / \mathrm{day}$ ), while all those with chronic active hepatitis were receiving immunosuppressive drugs (prednisolone 5-10 $\mathrm{mg} /$ day and azathioprine $75 \mathrm{mg} /$ day). Five of the patients with primary biliary cirrhosis were on penicillamine and a further four were receiving azathioprine $(75 \mathrm{mg} /$ day). None of the patients were transfused before taking the blood samples.

Venous blood samples were allowed to clot for two hours at room temperature before separation of 
serum which, if not used immediately, was stored in aliquots at $-70^{\circ} \mathrm{C}$. Serum from 16 healthy laboratory personnel, aged between 20 and 40 years, was used as control. A control serum pool was prepared from the sera of six controls and also stored in aliquots at $-70^{\circ} \mathrm{C}$. Most samples were assayed immediately but if storage was necessary the serum samples were assayed within one month and the appropriate control samples included.

\section{PREPARATION OF POLYMORPHONUCLEAR \\ LEUCOCYTES}

The polymorphonuclear leucocytes were isolated from normal human venous blood by dextran sedimentation and Ficoll-Triosil (density $=1.077$ $\mathrm{g} / \mathrm{ml}$ ) gradient centrifugation at $400-450 \mathrm{~g}$. The cell pellet was washed twice with Hank's balanced salt solution (HBSS) at $\mathrm{pH} 7.4$ without antibiotics and containing $1 \%$ gelatin, $0.5 \mathrm{mM}$ HEPES and $5 \mathrm{U} / \mathrm{ml}$ preservative-free heparin. The residual erythrocytes were lysed with distilled water for 20 seconds and polymorphonuclear leucocytes were resuspended in HBSS to a final concentration of $2 \times 10^{6} / \mathrm{ml}$. More than $90 \%$ of cells were viable, as assessed by exclusion of trypan blue.

\section{MEASUREMENT OF POLYMORPHONUCLEAR}

LEUCOCYTE LOCOMOTION

The method used was based on that of Aggett et al, ${ }^{12}$ as modified by Rajkovic et al. ${ }^{13}$ Briefly, the lower compartments of the multiwell assembly, containing an absorbent cellulose disc, were filled with either $5 \%$ test serum as the stimulus or HBSS alone. The upper compartments contained the polymorphonuclear leucocyte suspension and were separated from the lower compartments by $3 \mu \mathrm{m}$ pore membrane filters. The chambers were incubated for 90 minutes at $37^{\circ} \mathrm{C}$. The filters were then processed as described earlier ${ }^{12}$ and the distance travelled by the cells through the filters measured using the 'leading front' technique of Zigmond and Hirsch. ${ }^{14}$ The results were expressed as the percentage of the control serum pool value. This assay cannot distinguish between chemokinesis and chemotaxis but the conditions are such that chemotaxis may be favoured. ${ }^{13}$

SERUM COMPLEMENT AND IMMUNOGLOBULINS Serum concentrations of immunoreactive $C_{3}$ were determined by radial immunodiffusion against rabbit antiserum and $C_{5}$ by rocket immunoelectrophoresis against specific rabbit antiserum (Behring Diagnostics, Hoechst UK Ltd, Hounslow, UK). Results were expressed as the percentage activity of the control serum pool included as a standard in each assay.
Immunoglobulins $\mathrm{M}, \mathrm{G}$, and $\mathrm{A}$ were assayed by the radial immunodiffusion method of Fahey and McKelvey ${ }^{15}$ using M-Partigen plates (Behring Diagnostics, Hoechst UK Ltd, Hounslow, UK).

\section{STATISTICAL CALCULATION}

As the data are not distributed normally, the median and range of values is given for all results. Comparison of differences between patient groups was performed using the Wilcoxon's rank sum test and considered to be significant at the $5 \%$ level. The frequencies were analysed by the Fischer's Exact Probability or Fourfold Table tests.

\section{Results}

The effectiveness of the serum as an attractant for normal polymorphonuclear leucocytes was significantly reduced, as defined by levels lower than two standard deviations of the mean for control sera $(p<0.05)$, in $18(66 \%)$ of the 27 patients with alcoholic liver disease as compared with only five (29\%) of the 17 patients with chronic active hepatitis. Serum attractant activity was within the normal range in all 13 patients with primary biliary cirrhosis, including the six with cirrhosis, and in the two patients in the alcoholic liver disease group who had fatty change of the liver only (Fig. 1).

Although the severity of the serum defect was no greater in patients with alcoholic cirrhosis than in those with chronic active hepatitis, with median attractant activity in patients with the defect of 53\% $(0-82 \%)$ and $57 \%(21-77 \%)$ repectively, the difference in the frequency of defective sera between the two groups was statistically significant $(p<0.05)$. Those patients in the alcoholic cirrhosis group who had the serum defect also had significantly more severe liver disease than those without the defect, as assessed by liver function tests. Correlations between serum attractant activity and serum concentrations of albumin and bilirubin were statistically significant $(r=0.51, \quad p<0.01$ and $r=-0.48, p<0.02$ respectively). Thus the patients with alcoholic hepatitis, having the most severe abnormalities in liver function tests were also found to have the most severe serum attractant defects, with median activity of $47 \%(23-69 \%)$ when compared to the other groups of patients studied $(p<0.05)$.

In patients with chronic active hepatitis neither the frequency or the severity of the serum defect were related to the presence of cirrhosis (the defect being found in two of nine patients with, and three of eight patients without cirrhosis) or to the severity of liver disease, as assessed by changes in liver function tests. 
Fig. 1 Movement of normal polymorphonuclear leucocyte towards sera from controls and patients with chronic liver disease. $A L D=$ alcoholic liver disease; $C A H=$ chronic active hepatitis; $P B C=$ primary biliary cirrhosis. $O$ cirrhosis, $\Delta$ alcoholic hepatitis, $\Delta$ fatty change, normal range (mean $\pm 2 S D)$, • controls or patients without cirrhosis.

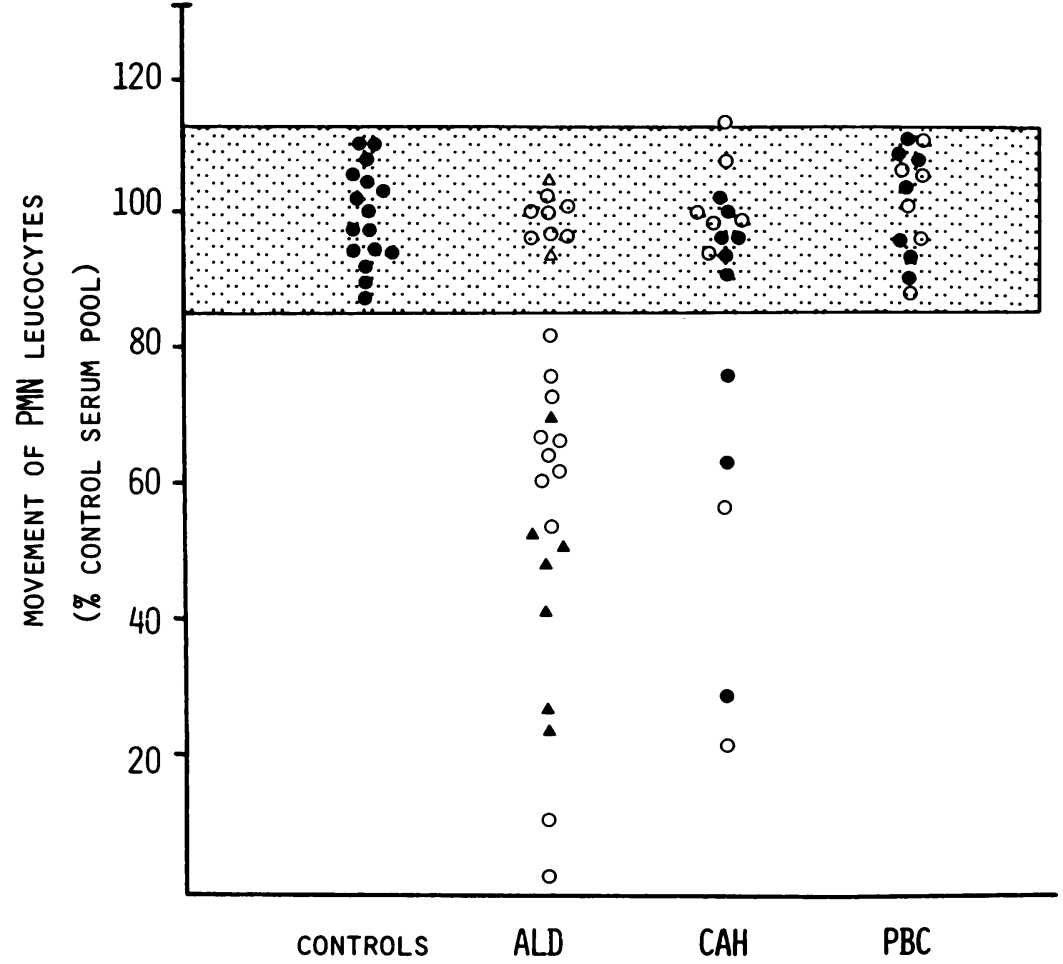

Defective serum stimulatory activity was seen in all seven patients with alcoholic cirrhosis and proven bacterial infection at the time of study, but the serum defect was also present in a high proportion $(61 \%)$ of the remaining 18 patients who did not have infection (Fig. 2). The difference was not statistically significant $(p=0.066)$. The serum attractant activity in those patients with infection (median $=53 \%$ with a range of $0-73 \%$ ) was similar to the serum activity in those without infection (median $=69 \%$, range $25-104 \%$ ) .

No apparent relationship could be found between the serum defect and the administration of immunosuppressive drugs in patients with chronic active hepatitis as both those with, and those without, the defect were receiving the drugs in comparable dosage.

\section{RELATION TO SERUM COMPLEMENT AND IMMUNOGLOBULINS}

Serum concentrations of complement components $\mathrm{C}_{3}$ and $\mathrm{C}_{5}$, measured in 11 cases of alcoholic liver disease, 10 cases of chronic active hepatitis, and five of primary biliary cirrhosis revealed low concentrations of $\mathrm{C}_{3}$ in one case of alcoholic cirrhosis, low
$\mathrm{C}_{5}$ in two cases of chronic hepatitis, and low concentrations of both $\mathrm{C}_{3}$ and $\mathrm{C}_{5}$ in one case each of alcoholic cirrhosis and chronic active hepatitis. While in those two patients with alcoholic cirrhosis who had low complement levels the deficiency was associated with reduced serum stimulatory activity (9\% and $52 \%$ of normal serum pool activity), in those patients with chronic active hepatitis who had markedly reduced complement levels the serum attractant activity was within the normal range.

Concentrations of serum $\operatorname{IgG}, A$, and $M$, measured in 15 of the patients with alcoholic liver disease, 10 with chronic active hepatitis, and five with primary biliary cirrhosis were, in general, raised (Table) and there was no correlation with the serum attractant activity.

\section{Discussion}

In early reports, already referred to, the high incidence of serum attractant defects in patients with chronic liver disease was largely associated with the presence of cirrhosis. Similarly, in the present study, among patients with alcoholic liver disease the defect was present only in those with cirrhosis. In 
Fig. 2 Movement of normal polymorphonuclear leucocytes towards defective sera from patients with alcoholic cirrhosis in presence and absence of bacterial infection.

$\ldots$ normal range (mean \pm 2

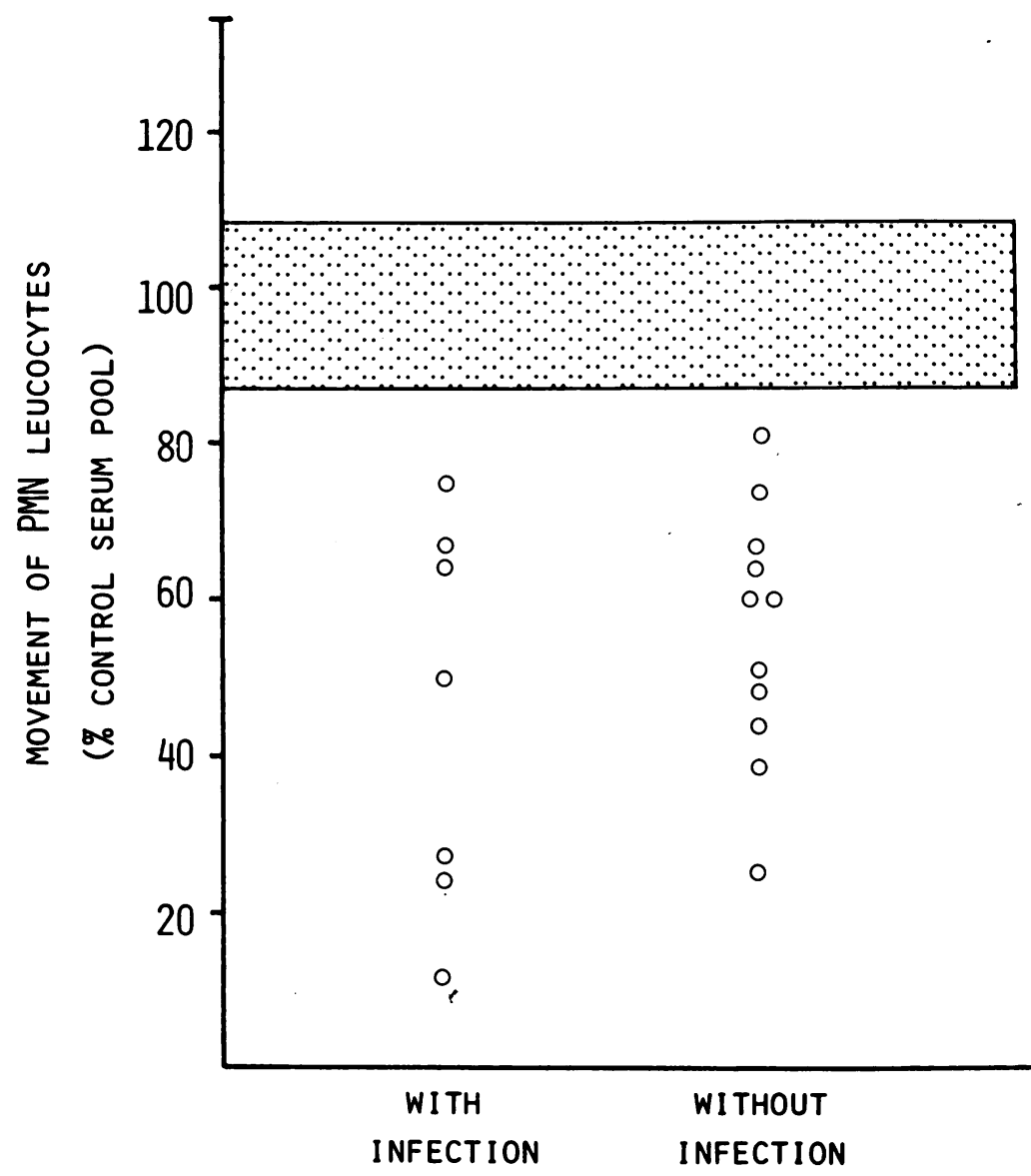

patients with chronic active hepatitis, however, the defect was found with a similar frequency in those with or without cirrhosis and in patients with primary biliary cirrhosis, nearly $50 \%$ of whom had cirrhosis, serum attractant activity was within the normal range.

In the present series there is a strong correlation between the serum attractant activity and serum concentrations of albumin and bilirubin in patients with alcoholic liver disease. Furthermore, the patients with alcoholic hepatitis who had the highest serum bilirubin concentrations also had the lowest serum attractant values. No such relationship was observed in patients with chronic active hepatitis and in the complete absence of serum defects in patients with primary biliary cirrhosis, this suggests that the aetiology of liver disease may play a crucial role in the generation of such serum defects. There is evidence in the literature to suggest that bilirubin may have an adverse effect on polymorphonuclear leucocyte function ${ }^{16}$ and, hence, it may contribute to the apparently defective stimulation of normal polymorphonuclear leucocyte by sera from patients with alcoholic liver disease seen in this study. This is unlikely, however, to be the mechanism of the serum defect in patients with chronic active hepatitis as in these patients no relationship between the serum attractant activity and concentrations of serum bilirubin could be found. A direct toxic effect of ethanol in the patients with alcoholic liver disease can be excluded as the blood samples were not taken until 48 to 72 hours after admission to hospital.

The principal serum factor involved in stimulation of polymorphonuclear leucocyte locomotion, the $\mathrm{C}_{5 \mathrm{a}}$ fragment, is produced by cleavage of the $\mathrm{C}_{5}$ complement component. This activation of complement occurs in vivo mostly as a result of bacterial invasion and in the in vitro assay system used in the present study, as a result of interaction between the cellulose fibres in the lower compartment of the 
Table Liver function tests, immunoglobulins and serum attractant activity (median and range) in patients with chronic liver disease

\begin{tabular}{|c|c|c|c|c|c|}
\hline & \multicolumn{2}{|c|}{ Alcoholic liver disease [27] } & \multirow{2}{*}{$\begin{array}{l}\text { Chronic active } \\
\text { hepatitis [17] }\end{array}$} & \multirow{2}{*}{$\begin{array}{l}\text { Primary biliary } \\
\text { cirrhosis [13] }\end{array}$} & \multirow[b]{2}{*}{ Normal range } \\
\hline & Hepatitis & Cirrhosis & & & \\
\hline Albumin $(\mathrm{g} / \mathrm{l})$ & $\begin{array}{l}26(24-37)^{*} \\
{[7]}\end{array}$ & $\begin{array}{l}37(20-47) \\
{[18]}\end{array}$ & $\begin{array}{l}37(30-50) \\
{[17]}\end{array}$ & $\begin{array}{l}35(30-43) \\
{[13]}\end{array}$ & $35-50$ \\
\hline Bilirubin $(\mu \mathrm{mol} / \mathrm{l})$ & $\begin{array}{l}291(46-551) \dagger \\
{[7]}\end{array}$ & $\begin{array}{l}18 \cdot 5(5-177) \\
{[18]}\end{array}$ & $\begin{array}{l}29(10-420) \\
{[17]}\end{array}$ & $\begin{array}{l}38(4-185) \\
{[13]}\end{array}$ & $3-30$ \\
\hline Alkaline phosphatase (IU/l) & $\begin{array}{l}259(136-415) \\
{[7]}\end{array}$ & $\begin{array}{l}130(71-252) \\
{[18]}\end{array}$ & $\begin{array}{l}100(53-246) \\
{[16]}\end{array}$ & $600(210-1340) \dagger$ & $30-85$ \\
\hline AST (IU/l) & $220(77-309) \div$ & $\begin{array}{l}33(26-120) \\
{[17]}\end{array}$ & $\begin{array}{l}29(16-500) \\
{[15]}\end{array}$ & $\begin{array}{l}75(52-164) \\
{[13]}\end{array}$ & $7-40$ \\
\hline Prothrombin time (sec) & $\begin{array}{l}24(17-60) \\
{[7]}\end{array}$ & $\begin{array}{l}19(13-53) \\
{[14]}\end{array}$ & $\begin{array}{l}14 \cdot 5(13-42) \\
{[12]}\end{array}$ & $\begin{array}{l}14(12-16) \\
{[13]}\end{array}$ & 13 \\
\hline $\operatorname{IgA}(\mathrm{g} / \mathrm{l})$ & $\begin{array}{l}6 \cdot 0(4 \cdot 8-8 \cdot 4) \\
{[3]}\end{array}$ & $\begin{array}{l}5 \cdot 8(1 \cdot 6-10 \cdot 2) \\
{[12]}\end{array}$ & $\begin{array}{l}2 \cdot 45(1 \cdot 2-6 \cdot 65) \\
{[10]}\end{array}$ & $\begin{array}{l}2 \cdot 5(1 \cdot 45-6 \cdot 6) \\
{[5]}\end{array}$ & $1 \cdot 25-4 \cdot 25$ \\
\hline $\operatorname{IgG}(\mathrm{g} / \mathrm{l})$ & $\begin{array}{l}9 \cdot 5(8 \cdot 6-20 \cdot 0) \\
{[3]}\end{array}$ & $\begin{array}{l}18 \cdot 5(10 \cdot 5-28 \cdot 5) \\
{[12]}\end{array}$ & $\begin{array}{l}12 \cdot 0(5 \cdot 5-18 \cdot 0) \\
{[10]}\end{array}$ & $\begin{array}{l}17 \cdot 7(12-29) \\
{[5]}\end{array}$ & $5-16$ \\
\hline $\operatorname{IgM}(\mathrm{g} / \mathrm{l})$ & $\begin{array}{l}3 \cdot 9(1 \cdot 05-4 \cdot 2) \\
{[3]}\end{array}$ & $\begin{array}{l}2 \cdot 28(0 \cdot 19-3 \cdot 45) \\
{[12]}\end{array}$ & $\begin{array}{l}1 \cdot 66(0 \cdot 9-8 \cdot 4) \\
{[10]}\end{array}$ & $\begin{array}{l}2 \cdot 75(1 \cdot 1-7 \cdot 95) \\
{[5]}\end{array}$ & $0 \cdot 5-2 \cdot 0$ \\
\hline $\begin{array}{l}\text { Serum attractant activity } \\
(\% \text { serum pool activity) } \\
\text { Frequency of defective sera }\end{array}$ & $47(23-69)^{*}$ & $\begin{array}{l}72 \cdot 5(0-102) \\
27^{*}\end{array}$ & $\begin{array}{l}96(21-116) \\
5 / 17\end{array}$ & $\begin{array}{l}104(88-112) \\
0 / 13\end{array}$ & $87-112$ \\
\hline
\end{tabular}

Figures in square brackets represent number of patients studied.

$* \mathrm{p}<0.05+\mathrm{p}<0.01$.

chemotaxis chamber and the complement system. The deficiency of complement, reported to be reponsible for defects of serum attraction in patients with fulminant hepatic failure ${ }^{17}$ did not appear to be reponsible for the defect in any of the patient groups included in the present study. Similarly, high concentrations of IgA and G, previously reported $^{918}$ to be associated with serum attractant defects and having a direct inhibitory effect on polymorphonuclear leucocyte function in patients with alcoholic cirrhosis, had no relationship with the serum defect in our patients.

Although infection, especially in the form of spontaneous bacterial peritonitis, is also common in patients with chronic active hepatitis (unpublished results), in the present study bacterial infection was only recorded in those with alcoholic cirrhosis. This may in part be owing to the low incidence of ascite in the group of chronic active hepatitis patients investigated. A number of studies, already referred to, suggest a close association between the presence of bacterial infection and defective serum attraction in patients with alcoholic cirrhosis but this does not appear to be the case in the present study.

Although it is likely that there are many factors underlying the susceptibility to infection of patients with alcoholic cirrhosis, the defect of serum attraction may be of key importance.
We are indebted to Professor J F Soothill and Mrs Betty Harvey for valuable advice. The support of Immuno Ltd, and the Peel Foundation is also gratefully acknowledged. Dr Abdul Yousif-Kadaru was in receipt of a medical fellowship from the Arab-British Chamber of Commerce.

\section{References}

1 Whipple RL, Harris JF. E-coli septicaemia in Laennec's cirrhosis of the liver. Ann Intern Med 1950; 33: 462-6.

2 Tisdale WA. Spontaneous colon bacillus bacteraemia in Laennec's cirrhosis. Gastroenterology 1961; 40: 141-8.

3 Jones EA, Crowley N, Sherlock S. Bacteraemia in association with hepatocellular and hepatobiliary disease. Postgrad Med J 1967; 43: 7-11.

4 Martin WJ, McHenry MC, Wellman WE, Baggenstoss AH. Severe liver disease complicated by bacteraemia. Arch Intern Med 1962; 109: 555-62.

5 Correia JP, Conn HO. Spontaneous bacterial peritonitis in cirrhosis. Med Clin North Am 1975; 59: 963-81.

6 Snyder N, Atterbury CE, Correia JP, Conn HO. Increased concurrence of cirrhosis and bacterial endocarditis. A clinical and postmortem study. Gastroenterology 1977; 73: 1107-13. 
7 Demeo AN, Andersen BR. Defective chemotaxis associated with serum inhibitor in cirrhotic patients. $N$ Engl J Med 1972; 286: 735-40.

8 Maderazo EG, Ward PA, Quintiliani R. Defective regulation of chemotaxis in cirrhosis. $J$ Lab Clin Med 1975; 85: 621-30.

9 Van Epps DE, Strickland RG, Williams RS. Inhibitors of leucocyte chemotaxis in alcoholic liver disease. $A m \mathrm{~J}$ Med 1975; 59: 200-7.

10 Magluilo E, Benzi-Cipelli R. Impaired leukotaxis in viral hepatitis B. N Engl J Med 1975; 293: 303-4.

11 Feliu E, Geugerot MA, Hakim J et al. Blood polymorphonuclear dysfunction in patients with alcoholic cirrhosis. Eur J Clin Invest 1977; 7: 571-7.

12 Aggett PJ, Harries JT, Harvey BAM, Soothill JF. An inherited defect in neutrophil mobility in Schwachman syndrome. J Paediatr 1979; 94: 391-4.

13 Rajkovic IA, Yousif-Kadaru AGM, Wyke RJ, Williams R. Multiwell filter techniques for measuring polymorphonuclear leucocyte locomotion in vitro - activation of serum in situ. J Clin Lab Immunol 1983; 10: $155-7$.

14 Zigmond SH, Hirsch HG. Leucocyte locomotion and chemotaxis: new methods for evaluation and demonstration of cell-derived chemotactic factor. J Exp Med 1973; 137: 387-410.

15 Fahey JL, McKelvey EM. Quantitative determination of serum immunoglobulin in antibody-agar plates. $J$ Immunol 1965; 94: 84-90.

16 Thong YH, Rancis V. Bilirubin inhibits hexose monophosphate shunt activity of phagocytozing neutrophils. Acta Paediatr Scand 1977; 66: 757-60.

17 Wyke RJ, Yousif-Kadaru AGM, Rajkovic IA, Williams R. Serum stimulatory activity and polymorphonuclear leucocyte movement in patients with fulminant hepatic failure. Clin Exp Immunol 1982; 50: 442-9.

18 Van Epps DE, Williams RC Jr. Suppression of leucocyte chemotaxis by human $\operatorname{IgA}$ myeloma components. J Exp Med 1976; 144: 1227/42. 